\title{
Revolutionary versus Reactionary: Contrasting Portuguese and Spanish Civil-Military Relations during Democratization
}

\begin{abstract}
The military is an important factor for the success or failure of democratization processes. Portugal and Spain provide two paradigmatic cases. Despite their socio-economic, political and cultural similarities, these countries developed very different civil-military relations which significantly impacted their transitions. After having handed power over to a civilian dictator, Salazar, the Portuguese military eventually caused the downfall of his authoritarian Estado Novo regime and steered the transition to democracy. In contrast the Spanish military, which had helped Franco defeat the Second Republic, remained loyal to the dictator's principles and, after his death, obstructed the democratization process. Drawing on primary and secondary sources, this interdisciplinary article contrasts the challenges posed by the military and the policies implemented by the Iberian governments to depoliticize and control it. It shows that the failed coups d'état in these countries helped tighten civilian control and paved the way for democratic consolidation. Using a policy instruments comparative framework, this paper demonstrates that not only the attitudes of the military but also the tools used to keep them under control were substantially different in Portugal and Spain. Historical legacies from the Spanish Civil War, Second World War and Colonial conflicts, as well as contextual factors serve to explain this variation.
\end{abstract}

\section{Keywords}

Civil-military relations; coup d'état, democratization; military; transitions; policy instruments; Portugal; Spain; war

\section{The Military Dimension of Political Transitions}

History shows that the military sometimes influence, blackmail or displace governments. The tensions between the political and military sphere continue in the twenty-first century. The coups in Niger (2010), Guinea-Bissau (2012), Egypt (2013) and Thailand (2014) are the latest examples of the military successfully overturning governments. Moreover, the armed forces are 
hindering democratic consolidation in more subtle ways in several countries. ${ }^{1}$ The analysis of civil-military relations helps understand transitional processes and potential threats to newly established democracies. Portugal and Spain provide two paradigmatic cases of transitions in which the military became one of the main challenges. ${ }^{2}$ The lessons they provide shed light on the complexities and problems other countries are facing or may face in the future.

Spain and Portugal successfully implemented civilian control of the armed forces ${ }^{3}$ and developed democratic political systems, but the paths they followed differed widely. Whereas in Spain the reactionary armed forces remained the bastion of authoritarianism and loyal to Franco, in Portugal a group of revolutionary militaries overthrew the dictatorial Estado Novo.

Following a long tradition of military interventionism and "pronunciamentos" which can be traced back to aftermath of the Napoleonic Wars, ${ }^{4}$ a military putsch ended the Portuguese First Republic in 1926. In 1932, the military appointed Salazar, a university professor, Prime Minister (PM). He inaugurated a civilianized dictatorship with fascist traits called Estado Novo. Although the military maintained significant autonomy and presence in the government and administration, Portuguese civil-military relations were unstable. Salazar experienced at least 15 military coups attempts between 1931 and $1965 .^{5}$ He used the threats of Spanish Civil War and Second World War as well as the cooperation with the NATO allies to reinforce his sway on the armed forces. However, the Colonial Wars (1961-1975) emerged as an important source

\footnotetext{
${ }^{1}$ Aqil Shah 'Constraining consolidation: military politics and democracy in Pakistan (2007-2013).' Democratization, 21 no. 6 (2014): 1007-1033, p. 1027; Nassif Bou 'Coups and nascent democracies: the military and Egypt's failed consolidation.' Democratization, 24 no. 1 (2017): 157-174, p. 157.

${ }^{2}$ Richard Gunther, P. Nikiforos Diamandouros and Dimitri A. Sotiropoulos, Democracy and the State in the New Southern Europe. Oxford: Oxford University Press, 2006, p. 19.

${ }^{3}$ For a unified conceptual framework for evaluating the degree of civilian control in new democracies, see Aurel Croissant, David Kuehn, Paul Chambers and Siegfried O. Wolf, 'Beyond the fallacy of coup-ism: conceptualizing civilian control of the military in emerging democracies.' Democratization, 17, no. 5 (2010): 950-975, pp. 955-963.

${ }^{4}$ José J. Olivas 'The deep roots of the Carnation Revolution: 150 years of military interventionism in Portugal.' Portuguese Journal of Social Science, 13 no. 2 (2014): 215-231, pp. 215-218.

5 José M. Ferreira, O Comportamento Político Dos Militares: Forças Armadas E Regimes Políticos Em Portugal Durante O Século XX. Lisbon: Estampa, 1992, pp. 329-330.
} 
of disagreement between the government and the military. Civil-military tensions worsen during Caetano's rule (1968-1974) until a coup led by the left-wing middle-rank officers' group called the Armed Forces Movement (MFA) put an end to the Estado Novo on 25 April 1974.

The Carnations Revolution started a transitional process which, from the civil-military perspective, was very convoluted. From 1974 to 1976, the military controlled not only the armed forces but also all of the governing institutions. Two important military coups were neutralized; a right-wing coup in March and a left-wing coup in November $1975 .{ }^{6}$ From 1976 onwards, the military influence on politics dwindled gradually. The dissolution in 1982 of the military Council of the Revolution and Portugal's EEC membership in 1986 became major milestones in the process of democratic consolidation. ${ }^{7}$

In Spain, the socio-political situation was very unstable during the Second Republic (19311939). On 17 July 1936, important sectors of the military rebelled against the left-wing coalition Frente Popular triggering a civil war. As in the case of Portugal, this military uprising can be considered the latest example of a long trend of military mutinies and "pronunciamientos" initiated during the Napoleonic invasions. ${ }^{8}$ General Franco's Nationalist camp won the war in 1939 and the military became the backbone of the new dictatorship. ${ }^{9}$ Franco did not have to face any major threat from the military, which remained loyal and perceived itself as guardian of its traditions and values even after his death in $1975 .^{10}$

\footnotetext{
${ }^{6}$ Paul C. Manuel, Uncertain Outcome: The Politics of the Portuguese Transition to Democracy, Lanham: University Press of America, 1995, pp. 81-83 and pp. 125-128.

${ }^{7}$ Paul C. Manuel, The Challenges of Democratic Consolidaion in Portugal: Political, Economic, and Military Issues, 1976-1991.Westport: Praeger Publishers, 1996, pp. 74-76.

${ }^{8}$ Miguel Alonso Baquer, 'The Age of Pronunciamientos' in Armed Forces and Society in Spain Past and Present edited by Rafael Bañón Martínez and Thomas M. Barker Boulder: Social Sience Monographs, 1988, pp. 117, 145.

${ }^{9}$ Paul Preston, The Politics of Revenge: Fascism and the Military in Twentieth-Century Spain. Madrid: Unwin Hyman, 1990, pp. 103-105.

${ }^{10}$ Gabriel Cardona, Franco Y Sus Generales, La Manicura Del Tigre, Madrid: Temas de Hoy, 2001, p. 213.
} 
Spanish transition has been extensively studied and is considered an example of success. ${ }^{11}$ However, in Spain the path towards democratization was not an easy one. The military, which did not endorse the political reforms nor did it participate in the core decisions during the transition became an obstacle. ${ }^{12}$ Once Franco's appointed successor, King Juan Carlos, showed commitment to profound political reforms, military discontent grew and subordination weakened. The military then became the main threat for the transition to democracy. The coup attempt on 23 February $1981(23 \mathrm{~F})$ has caught the attention of many scholars. However this was only of among at least six military plots against democracy between 1978 and 1985, including a plan for the assassination of the King and the Government in Coruña in June $1985 .{ }^{13}$

In sum, there is an empirical puzzle: very similar countries experiencing similar political transformations developed very different civil-military relations and levels of control of the military. The attitude of the armed forces during the transition in Portugal and Spain was almost diametrically opposed and in both cases problematic for democratization. The military in Portugal was defining and leading the reforms while obstructing them in Spain.

This comparative interdisciplinary paper combines archival work ${ }^{14}$ with a range of political science, sociology and history secondary sources to identify trends in the complex relationship between governments and the military, and explain the main factors which shaped the abovementioned distinct trajectories in Portugal and Spain. First, it outlines the most important

\footnotetext{
${ }^{11}$ Juan Linz, 'La Transición Española En Perspectiva Comparada', in Historia De La Transición edited by Javier Tussell and Álvaro Soto. Madrid: Alianza Universidad, 1996; Richard Gunther, José Ramón Montero and Joan Botella. Democracy in Modern Spain. New Haven: Yale University Press, 2004, pp. 82, 107, 115.

${ }^{12}$ Felipe Agüero, Soldiers, Civilians, and Democracy: Post-Franco Spain in Comparative Perspective. Baltimore: John Hopkins University Press, 1995, pp. 61-65.

${ }^{13}$ Díaz Fernández, Antonio M. Los Servicios De Inteligencia Españoles. Madrid: Alianza, 2005, pp. 221-224.

${ }^{14}$ This paper is part of a wider research conducted over six years in London, Lisbon and Madrid, which resulted in the publication of other works, such as those cited in footnote 4 and 60 . The archives used in this article are: the Arquivo do Conselho da Revolução (ACR) in Arquivo Nacional Torre do Tombo, Lisbon; the Arquivo Histórico Militar (AHM), Lisbon; and the Audio Archive of Fundación Ortega y Gasset (FOG), Madrid, which includes interviews recorded throughout the 1980s with prominent military and politicians during Spanish transition.
} 
political and military developments during these transitional periods in both countries. Then, using an adaptation of Hood's framework for the study of tools of government, ${ }^{15}$ it highlights significant discrepancies in the policy instruments and overall strategy used by the Iberian governments to control the military. Finally, following a neo-institutional perspective, ${ }^{16}$ this paper examines some "historical" and "constant causes" $" 17$ and shows that the differences in control strategies and dynamics of civil-military relations were fundamentally triggered by the legacies of past events such as the Spanish Civil War, Second World War and Colonial Wars, and later shaped by the ideational and institutional contexts during the transitions.

Table 1 Chronology of Events

\begin{tabular}{|c|c|c|}
\hline & Portugal & Spain \\
\hline 1973 & Oil crisis & $\begin{array}{l}\text { Francoist PM, Carrero Blanco, is assassinated by } \\
\text { ETA. Reform of the military curricula }\end{array}$ \\
\hline 1974 & $\begin{array}{l}\text { Failed military coup in March. Coup of } 25 \text { April } \\
\text { (Carnations Revolution) succeeds. Negotiation } \\
\text { for the independence of the colonies. Right } \\
\text { wing coup attempt (September) }\end{array}$ & $\begin{array}{l}\text { The clandestine Democratic Military Union } \\
\text { (UMD) is created }\end{array}$ \\
\hline 1975 & $\begin{array}{l}\text { Right-wing coup attempt (March). First Pact } \\
\text { MFA-Political Parties and democratic elections } \\
\text { (April). Left-wing coup attempt (November). } \\
\text { Council of the Revolution is established }\end{array}$ & $\begin{array}{l}\text { Last executions of the regime ( } 2 \text { ETA and } 3 \text { FRAP } \\
\text { members). Sahara sovereignty is transferred to } \\
\text { Morocco and Mauritania. Death of Franco. UMD } \\
\text { is dismantled and its members arrested }\end{array}$ \\
\hline 1976 & $\begin{array}{l}\text { Second Pact MFA-Political Parties. MFA } \\
\text { apparatus is dismantled. Portuguese } \\
\text { Constitution is approved. PS wins the } \\
\text { legislative elections }\end{array}$ & $\begin{array}{l}\text { Suárez is appointed PM. Political Reform Act for } \\
\text { the self-dissolution of the Francoist regime is } \\
\text { approved in the Congress and ratified by } \\
\text { referendum }\end{array}$ \\
\hline 1977 & & $\begin{array}{l}\text { UCD wins the legislative elections. A unified } \\
\text { Defense Ministry is established }\end{array}$ \\
\hline 1978 & Stand-by agreements with the IMF & $\begin{array}{l}\text { Spanish Constitution is issued. "Operación } \\
\text { Galaxia" plot is neutralized }\end{array}$ \\
\hline 1979 & $\begin{array}{l}\text { Centre-right coalition "Aliança Democrática" } \\
\text { wins the legislative elections }\end{array}$ & UCD wins the legislative elections \\
\hline 1980 & $\begin{array}{l}\text { PM Sá Carneiro and Defense Minister Amaro } \\
\text { da Costa die in a plane crash }\end{array}$ & $\begin{array}{l}\text { National Defense and Military Organization Law } \\
\text { is enacted }\end{array}$ \\
\hline 1981 & & $\begin{array}{l}\text { Suárez resigns. } 23 \mathrm{~F} \text { coup is neutralized. Calvo } \\
\text { Sotelo becomes PM }\end{array}$ \\
\hline 1982 & $\begin{array}{l}\text { Constitutional Reform and National Defense } \\
\text { Law. The CR is abolished }\end{array}$ & $\begin{array}{l}\text { Spain becomes a member of NATO. PSOE wins } \\
\text { the legislative elections }\end{array}$ \\
\hline 1983 & PS wins the legislative elections & \\
\hline 1984 & $\begin{array}{l}\text { Stand-by agreements with the IMF. } \\
\text { Reunification of the secret services (SIRP) }\end{array}$ & $\begin{array}{l}\text { Organic Law of Defense and creation of the Chief } \\
\text { of the Joint of Staff (JEMAD) }\end{array}$ \\
\hline 1985 & PSD wins the legislative elections & Military coup in La Coruña is neutralized \\
\hline 1986 & Portugal becomes member of the EEC & $\begin{array}{l}\text { Spain becomes member of the EEC. NATO } \\
\text { membership validated by referendum. PSOE wins } \\
\text { the legislative elections }\end{array}$ \\
\hline
\end{tabular}

${ }^{15}$ Christopher Hood, The Tools of Government. London: Macmillan, 1983, pp. 4-6.

${ }^{16}$ Peter Hall and Rosemary Taylor, 'Political Science and the Three New Institutionalisms', Political Studies, 44 (1996): 936-957, pp.

${ }^{17}$ The distinction between "historical" and "constant causes" as factors producing continuity and change in Arthur L. Stinchcombe, Constructing Social Theories. Chicago: The University of Chicago Press, pp. 101-129. The section "Historical Legacies" addresses the former and "Contextual Factors" the latter. 


\section{The Portuguese Transition}

The Carnations Revolution was initiated by a military coup. On 25 April 1974, a group of MFA officers took control of Lisbon airport, radio and television broadcast centres and of the military headquarters in Lisbon and Oporto. They became the first agents of popular mobilization. ${ }^{18}$ Portuguese civil society backed the military rebels contributing to the surrender of Caetano and fall of the regime. ${ }^{19}$ The Estado Novo was defeated by the same element that created it: the military. Portuguese transition can be broadly divided into two different periods: the period of provisional governments (1974-1976) and that of constitutional governments (1976-1986).

\section{The Period of Provisional Governments}

After the fall of the Estado Novo on 25 April there was a period of instability, six different provisional governments and two military coups took place between the Carnations Revolution and the enactment of the new Constitution in 1976. This period saw the design and launch of the new democratic institutions. Political parties and class organizations were legalized and decolonization initiated. The MFA played a key role in shaping the process of institutional change. ${ }^{20}$ Military and government affairs were extremely intertwined. Military structures proliferated and overlapped with the political system. The militarization of politics accelerated the politicization of the armed forces.

The period of provisional or pre-constitutional governments may be subdivided in four distinct stages clearly marked by changes in civil-military relations. ${ }^{21}$ First, from April to September 1974, the new President of the Republic, General Spínola and the First Provisional Government

\footnotetext{
${ }^{18}$ Tiago Fernades, 'Rethinking pathways to democracy: civil society in Portugal and Spain, 1960s2000s’ Democratization, 22 no. 6 (2014): 1074-1104, p. 1084.

${ }^{19}$ Douglas Porch, The Portuguese Armed Forces and the Revolution, Stanford, Hoover Institute Press, 1977, pp. 92-93.

${ }^{20}$ Maria I. Rezola, Os Militares Na Revolução De Abril: O Conselho Da Revolução Ea Transição Para a Democracia Em Portugal, 1974-1976. Lisbon: Campo da Comunicação, 2006, pp. 71-72.

${ }^{21}$ Manuel, Uncertain Outcomes, pp. 139-143.
} 
led by the civilian Palma Carlos tried to moderate the MFA's revolutionary program. They attempted to slow down the decolonization and to re-establish a traditional hierarchical conception of the military. However, they failed to impose their views over those of the MFA and were obliged to resign. Palma Carlos was substituted by Colonel Vasco Gonçalves in July and Spínola by General Costa Gomes in September following social mobilizations orchestrated by the left.

The second stage, from September 1974 to March 1975, was characterized by the disputes among different factions within the MFA. After the crisis of September 1974, the MFA tried to reinforce its position by the purges of non-revolutionary officers ${ }^{22}$ and the institutionalizing its power. The creation of the MFA Assembly, the Higher Council of the MFA and the first Pact between the MFA and the political parties are examples of this effort. The latter granted the MFA the surveillance and control of the drafting process of the new constitution and a decisive role in the election of the President. ${ }^{23}$ Left-wing political parties approached the MFA to acquire influence within the government, providing legitimacy to the military in exchange.

The MFA sheltered three main ideologically distinct subgroups. The "MFA-Moderates" headed by Majors Antunes and Lourenço, were linked to the Socialist Party, PS. This group gradually attracted many conservative officers too and dominated most of the military regions. The "MFA-Radicals" or gonçalvistas, led by Colonel Gonçalves, were close to the Portuguese Communist Party (PCP) and controlled the "Fifth Division" information services, the Navy and the radical military group Soldados Unidos Vencerão ${ }^{24}$ Finally, the "MFA-Populists", led by Major Otelo, were inspired by the Third World liberation movements, linked to left-wing

\footnotetext{
${ }^{22}$ The "saneamentos" by Decree-Law 634/74 (20 November 1974) follow other similar purges such as thoseformalized by Decree-Laws 178/74 (30 April 1974) and 309/74 (8 July 1894).

${ }^{23}$ Arquivo do Conselho da Revolução (ACR), Lisbon, MFA/Partidos (84), Pacto MFA-Partidos Part I, Document 16 and Part II Document 14, April 1975 and 26 February 1976.

${ }^{24}$ Maria Carrilho, Democracia E Defesa: Sociedade, Política E Forças Armadas Em Portugal, Lisbon: Dom Quixote, 1994, pp. 66-67. The terms MFA-Moderates, MFA-Radicals and MFA-Populists are introduced by Manuel Ibid, pp. 107-109 and based on Eusebio Mujal Leon,
} 
parties such as the Revolutionary Party of the Proletariat (PRP) and the Popular Democratic Union (UDP), and controlled the Special Forces Unit COPCON.

Moreover, outside the MFA, there was a big group of military close to the centrist Democratic Popular Party (PPD) and to the centre-right Social Democratic Centre (CDS). They opposed to the idea of a socialist state and preferred more gradual changes. The most prominent figure of this group was General Spínola. ${ }^{25}$ Disputes about the institutionalization of the MFA, trade unionism and economic plans were recurrent within and between the armed forces and the government during this period. ${ }^{26}$

The third stage began with the failure of a right-wing military coup on 12 March 1975 . The MFA-Radicals and their revolutionary agenda were strengthened as a reaction against the failed coup. There were land seizures, collectivizations and nationalization of large companies. The Council of the Revolution (CR) was established to promote the political objectives of the MFA and to oversee the process of transition. ${ }^{27}$ The PS won the Constituent Assembly elections on 25 April 1975 and the level of social tensions increased especially within the left. This happened not only at the civilian level, between PCP and PS, but also between the different MFA factions. Social mobilizations and pressures from the MFA-Moderates and MFA-Populists forced the resignation of Gonçalves as PM in September 1975, marking the end of the third stage. ${ }^{28}$

The fourth stage coincided with the sixth provisional government (from September 1975 to July 1976). The new PM, Admiral Azevedo tried to reverse the revolutionary transformations

'Communism and Revolution in Portugal' in Eurocommunism and Détente edited by Rudolf Tokes. New York: New York University Press, 1978, pp. 282-287.

${ }^{25}$ Juan C. González Hernández, Desarrollo Político Y Consolidación Democrática En Portugal (1974-1998). Madrid: CIS, 1999, p. 52.

${ }^{26}$ ACR, MFA/Partidos (84), Institucionalização do MFA, Documents 1-37, 1975.

${ }^{27}$ ACR, Actas - Originais, volume 1 and Correspondência classificada do secretariado coordenador, volume 8, number 94, document 28, 27 March and 20 June 1975.

${ }^{28}$ ACR, Correspondência classificada do secretariado coordenador, volume 8, number 94, document 28, 'Autocrítica Revolucionária do COPCON e Proposta de Trabalho para um Programa 
attracting the criticism from the MFA-Radicals, MFA-Populists. At least 58 protests and acts of indiscipline took place in the Portuguese Armed Forces between September and November 1975. ${ }^{29}$ The rising tensions culminated in a left-wing military coup on 25 November 1975 . The moderate Lieutenant-Colonel Eanes successfully led the military operations to defeat the putsch. $^{30}$

The failure of the November 1975 coup contributed to discredit the most radical revolutionary theses and consolidated the hegemony of the MFA-Moderates. This was a tipping point in the political transformations and in the evolution of government policies for the control of the military. ${ }^{31}$ Many political and military figures understood then that the role of the military in politics should be reduced. The second Pact between the MFA and the political parties in February 1976 reflected this changing trajectory. It introduced the direct universal suffrage for the election of the President, abandoning the system of election through a joint session of the MFA and Legislative Assemblies. This change effectively initiated the military separation from politics which was later confirmed by the 1976 Constitution. The government aimed at a gradual demilitarization of politics and depoliticization of the armed forces.

\section{The Period of Constitutional Governments}

Crucial transformations for the consolidation of democracy took place during the period of constitutional governments (1976-1986). Electoral legitimacy replaced the revolutionary legitimacy and the political parties were emancipated from the MFA. ${ }^{32}$ The 1976 Constitution established that the governments should take steps towards the construction of a "socialist

Político'.

${ }^{29}$ Carrilho Ibid, 67.

${ }^{30}$ ACR Actas - Originais, volume 3, minutes of the CR reunion, 7 June 1976; Josep Sánchez Cervelló, A Revolução Portuguesa E a Sua Influência Na Transição Espanhola (1961-1976). Lisbon: Assirio \& Alvim, 1993, pp. 253-258.

${ }^{31}$ José M. Ferreira, Ensaio Histórico Sobre a Revolução De 25 De Abril - O Período Pré-Constitucional. Lisbon: INCM-SREC, 1983, pp. 175-176.

32 Juan C. González Hernandez, Ibid, p. 26. 
democratic state" and restricted the participation of the military in politics to the CR. In 1976, Mario Soares, leader of the PS, and António Ramalho Eanes, the candidate of the MFA-Moderates, were elected PM and President respectively. These leaders contributed to a new approach in the government policies for the control of the military.

However, the political instability continued due to the minority government, the fragmentation of the political spectrum and the continued tactical changes in political alliances. Portugal faced numerous socio-economic challenges, such as high inflation, budget deficits and unemployment, the normalization of relations with the former colonies, absorption of the more than 500,000 retornados (refugees), ${ }^{33}$ reactivation of Portuguese participation in NATO (suspended during the revolutionary period), and the negotiations for EEC membership. All these problems diverted resources and attention away from the required military reforms.

The sway of the military in politics remained higher than in most Western democracies. The functions and scope of the CR, although constitutionally limited, were still far-reaching. The CR had complete control over the military and veto power over most strategic political decisions. The CR was guarantor of the constitutional institutions with the capacity to enact military laws and control military promotions. The 1976 Constitution had also granted the CR with a legitimacy superior to that of the Assembly. This was problematic because part of the military leadership still championed the spirit of the revolution and a socialist type of democracy which contradicted the ideas held by the mainstream political parties that represented the majority of Portuguese voters. ${ }^{34}$

The Social Democratic Party, PSD (previously PPD) and the CDS became the main opposition to the power of the CR. In the 1979 interim elections and 1980 legislative elections, the

\footnotetext{
${ }^{33}$ José M. Ferreira, História De Portugal, Vol. 8: Portugal Em Transe. Lisbon: Estampa, 1994, pp. 86-91.

${ }^{34}$ Tom Gallagher, Portugal: A Twentieth-Century Interpretation, Manchester University Press, Manchester, 1983, pp. 230-239.
} 
centre-right coalition they integrated, Democratic Alliance, obtained the majority of the seats in the Assembly. PM Francisco Pinto Balsemão obtained the support of the PS in order to circumvent President Eanes' veto and launch the 1982 Constitutional Reform (Law 1/82). This reform eliminated all references to a "socialist democracy", reduced the powers of the President and, most fundamentally, abolished the CR.

NATO became the model for the reforms in the armed forces initiated by the Law of National Defence and the Armed Forces of 1982 (Law 29/82). This new law, result of an agreement among political parties, was crucial in redefining civil-military relations. It passed the control of the military and defence decisions from the President to the PM and charged the Defence Minister with managing day to day military affairs. ${ }^{35}$ President Eanes and his supporters eventually accepted that in order to consolidate democratization and enter the EEC, the armed forces should disengage completely from politics, professionalize, reform their structure and participate more actively in NATO. ${ }^{36}$ The process of transfer of powers from President Eanes and the military to the civilians in the government and parliament continued during Soares's coalition government PS/PSD (1983-1985) and later with Cavaco Silva's PSD governments (from 1985). When Soares won the 1986 presidential elections, replacing General Eanes, and Portugal joined the EEC, the reforms to consolidate a democratic Western type of civil-military relations had been already implemented and the principle of civilian supremacy was finally uncontested.

\footnotetext{
${ }^{35}$ Francisco P. Balsemão, 'The Constitution and Politics', in Portugal in the 1980's: Dilemmas of Democratic Consolidation edited by Kenneth Maxwell. London: Greenwood Press, 1986, pp. 202-207.

${ }^{36}$ Lawrence S. Graham, The Portuguese Military and the State: Rethinking Transitions in Europe and Latin America. Boulder: Westview Press, 1993, p. 41.
} 


\section{The Spanish Transition}

The Spanish transition was not the result of a military intervention as that of Portugal and Greece. It was a civilian-led process, facilitated by pressures from inside the regime and its apparatus. ${ }^{37}$ The socio-economic modernization in the 1960 s and early 1970 s was the main accomplishment of the Francoist regime but also an important factor for its demise. Spain had become an urbanized and industrialized country that attracted tourists and foreign capital. By the time of Franco's death, on 20 November 1975, there was a belief among the majority of civil society of the necessity of a democratic political system. The memory of the civil war made most stakeholders adopt a constructive approach. ${ }^{38}$ Spanish political elites, including the clandestine opposition parties and some members of the Francoist administration, with the support of intellectual and economic elites launched a transition into a western-type pluralistic democratic system. ${ }^{39}$ This transition can be broadly divided in two stages: the period of the Suárez and Calvo Sotelo governments (1976-1981) and that of the first González government (1982-1986).

\section{The Suárez and Calvo Sotelo Governments}

Franco died leaving King Juan Carlos as head of state and Carlos Arias Navarro as PM. Social and political contestation and the inability to conduct the reforms forced Arias's resignation. ${ }^{40}$ In July 1976, the King appointed the reformist Adolfo Suárez as PM. Suárez's party, Democratic Centre Union (UCD), won the first two general elections since 1936, in June 1977 and March 1979 and set into motion the process of democratization.

\footnotetext{
${ }^{37}$ Richard Fishman, 'Rethinking State and Regime: Southern Europe's Transition to Democracy.' World Politics, 42 no. 3 (1990): 422-440, pp. 438-439.

${ }^{38}$ Paloma Aguilar, 'Collective memory of the Spanish civil war: The case of the political amnesty in the Spanish transition to democracy.' Democratization, 4 no. 4 (2007): 88-109, pp. 103-105.

${ }^{39}$ Kerstin Hamann, 'The Pacted Transition to Democracy and Labour Politics in Spain.' South European Society and Politics, 2, no. 2 (1997): 110-138, pp. 111-114.

${ }^{40}$ Audio-archive Fundación Ortega y Gasset (FOG), Madrid, interview with Antonio Garrigues, 4 October 1984, cassette J9.
} 
Although a group of reformist generals held important positions during this period, a reactionary group of officers, known as the bunker dominated the senior ranks. A large proportion of military officers rejected the advent of democracy and adopted and attitude of "passive resistance" towards liberalization during the period of UCD governments. ${ }^{41}$ Several events contributed to military frustration: First, the evacuation of the Spanish Sahara protectorate that concluded in February 1976 dampened military pride. Second, legal self-dissolution of the regime by the Political Reform Act (Law 1/1977) was considered by many military as treason against Francoist principles and put some generals in a state of "total dissonance" with the reforms. ${ }^{42}$ Third, many senior generals considered the legalization of the Spanish Communist Party (PCE) during Easter 1977 another act of betrayal. ${ }^{43}$ Fourth, the restoration of the Catalan regional government Generalitat in September 1977 and the ongoing decentralization process, including the approval of the statutes of autonomy of the Basque Country, Catalonia, Galicia and Andalusia (1979-1980), were perceived as a threat to the unity of Spain. Finally the growing spiral of terrorist violence by groups such as ETA and GRAPO, for which the military was priority target, reached its peak in 1980.

Suárez, aware of the risks that some military officers represented, appointed the liberal General Gutiérrez Mellado as Deputy Prime minister (1976-1981) and Defence Minister (1977-79). Gutiérrez Mellado launched a series of reforms that aimed at the modernization and professionalization of the armed forces as a means to counter the influence of the bunker, and to facilitate military subordination. Nonetheless these reforms proved to be insufficient to consolidate civilian supremacy. For instance, the new legal framework left room for an ambiguous interpretation concerning the chain of command. ${ }^{44}$ Honour Trials and the Francoist oath to the flag were not abolished, conscientious objection was not regulated and the

\footnotetext{
${ }^{41}$ FOG, interview Lieutenant-General José Vega Rodríguez, 4 October 1986, cassette J19.

42 FOG, interview Antonio Garrigues, 4 October 1984, cassette J9bis.

${ }^{43}$ Paul Preston, The Triumph of Democracy in Spain, London: Routledge, 1986, p. 115.

${ }^{44}$ Fernando Puell de la Villa, Historia Del Ejército En España. Segunda Edición. Madrid: Alianza,
} 
promotion of reactionary officers continued. Military courts exceeded their functions by judging civilians and imposed soft sentences on military anti-democratic actions. In sum, UCD governments failed to persuade the armed forces of the necessity of reforms and were too permissive with anti-democratic attitudes. ${ }^{45}$

The perceived weakness of the UCD governments paved the way for what Foreign Affairs Minister Areilza called a state of "permanent military conspiracy". ${ }^{46}$ The power of the reactionary generals and the discrepancies among the more liberal ones weakened civilian supremacy. The severe sanctions imposed on the progressive Democratic Military Union (UMD) contrasted with the permissiveness vis-à-vis the reactionary propaganda and acts of indiscipline. The kid-glove treatment to overt antidemocratic attitudes reinforced the bunker's conviction of the likelihood of success of a military intervention. ${ }^{47}$

The first important coup attempt, the "Operación Galaxia" in November 1978 was foiled by the secret services. Although the government tried to play down the importance of the incident, the fact that many military officers were aware of the plot and did not denounce it meant that military loyalty to the government could not be taken for granted. ${ }^{48}$ Another attempt was thwarted in 1979. The Armored Division (DAC), a bastion of reactionary ideas led by General Torres Rojas plotted to take control of the Presidential Palace of Moncloa with the help of the Parachute Brigade stationed in Torrejón. The coup was delayed due to insufficient supply of ammunition and fuel. Eventually the coup was neutralized and Torres Rojas demoted.

The socio-economic and political problems that Suárez's government encountered became an additional source of military discontent and an alibi for potential intervention. The UCD

2005, p. 236.

${ }^{45}$ Julio Busquets and Juan C. Losada, Ruido de Sables: Las conspiraciones militares en la España del siglo XX. Barcelona: Crítica, 2003, pp. 135-144.

${ }^{46}$ FOG, interview José María de Areilza, 13 September 1984, cassette J8bis.

${ }^{47}$ Paul Preston, The politics of revenge, p. 161.

${ }^{48}$ Manuel Ballbé, Orden Público Y Militarismo En La España Constitucional (1812-1983). Madrid: 
government failed to solve the economic problems fostered by the second oil crisis in 1979 . Unemployment and the public deficit grew and military budgets were constrained. Suárez's minority government had to face strong political opposition, not only from the rival parties, but also from within the UCD. ${ }^{49}$ The growing discontent in Spanish society precipitated Suárez's resignation in January 1981 and his replacement by Leopoldo Calvo Sotelo in February.

The $23 \mathrm{~F}$ coup was the most important attempt and had a stronger impact on civil-military relations. On 23 February 1981, a group of Civil Guards led by Tejero occupied the Congress during the investiture session of the new PM, Leopoldo Calvo Sotelo. Thanks to the action of the King, the royal military household, the political parties and some loyal military, the coup failed and the plotters were incarcerated. The coup shocked Spanish society, which for the most part was unaware of the extent of the military threat. Live radio and TV coverage amplified its impact. Spaniards reacted strongly against the plot. The behaviour of the plotters during the coup and their trials embarrassed most military officers and became a tipping point in the ascendency of bunker within the ranks.

Calvo Sotelo's government undertook some important measures concerning military subordination, including the integration into NATO from 30 May 1982. However, the consolidation of military subordination continued to be an issue. Conspiratorial groups such as the Unión Militar Española continued to operate and the hardline coup 'Operación Cervantes' was aborted in October 1982. ${ }^{50}$

\section{The First González Government}

The landslide victory in October 1982 elections granted the socialist government a solid parliamentary majority to conduct reforms. The peaceful transfer of power to the socialist party

\footnotetext{
Alianza, 1983, pp. 472-473.

${ }^{49}$ Jonathan Hopkin, Party Formation and Democratic Transition in Spain: The Creation and Collapse of the Union of the Democratic Centre. New York: St Martin's Press, 1999, pp. 225-231.
} 
can be considered as the end of the military threat and a landmark in the transitional process. ${ }^{51}$ Felipe Gonzalez's government restructured and liberalized the economy, developed the autonomous communities' territorial model, negotiated the membership to EEC, introduced education and social reforms and, most importantly, profound transformations in the defence and military policies. This was the first left-wing government in more than four decades, and paradoxically it suffered much lower contestation to its reforms than the previous centre-right UCD governments.

Narcís Serra, an economist and former mayor of Barcelona, was appointed Defence Minister. González and Serra, conscious that ideological change within the ranks was not achievable in the short-term, concentrated their efforts on obtaining material obedience rather than endorsement, and on developing a regulatory framework to eliminate the ambiguity introduced by the UCD governments and reduce military autonomy. The reforms launched by the socialist government were far-reaching and served to consolidate civilian supremacy. ${ }^{52}$ This process was facilitated by Spain's membership in NATO which most military had advocated. ${ }^{53}$ González, who as leader of the opposition had previously been opposed to NATO, understood its importance with regard to military subordination and changed his discourse to the extent that, in 1986, PSOE led the "Yes" campaign in the referendum that confirmed NATO membership.

The military cooperated with these reforms because they were concerned with the future of the armed forces and individual prerogatives rather than because they fully endorsed democratic values. Probably the clearest expression of the success of the PSOE government was the

\footnotetext{
${ }^{50}$ Julio Busquets and Juan C. Losada Ibid, pp. 59-66.

${ }^{51}$ Juan Linz and Alfred Stepan. Problems of Democratic Transition and Consolidation: Southern Europe, South America, and Post-Communist Europe. Baltimore: Johns Hopkins University Press, 1996, p. 108.

${ }^{52}$ FOG, interviews General Sáez de Tejada and Admiral Liberal Lucini, 17 November 1987, cassette J25bis and 27 November 1987, cassettes J27 and J27bis.

${ }^{53}$ FOG, interview Lieutenant-General Ignacio Alfaro Arregui, 18 December 1987, cassette J33bis
} 
changing nature of military discontent. ${ }^{54}$ Protests then came from specific problems found during the implementation of the reforms, such as promotions and career patterns, preferential treatment of some units and structural deficiencies. Except for a failed plot by a small group of hardliners to assassinate the King and some members of the government during a military parade in La Coruña in 1985, no further serious challenge was posed to civilian supremacy. By 1986, most military had realized that Spain was better off under democracy.

\section{Different Policies and Instruments of Control}

This section captures the significant discrepancies in the policies and instruments for the subordination of the military in both countries at the beginning of their transitions, as well as the convergence in their control strategies after 1982. The comparative framework employed here is inspired by Hood's fourfold typology basic resources used by governments to exert control: organization, nodality, authority and treasure. ${ }^{55}$

\section{Coercive Power}

In Spain, the use of coercive force was not a significant element in the toolkit for controlling the military. Even at the height of military insubordination during the $23 \mathrm{~F}$ coup, its utilization remained minimal. The corporatism of the military made extremely difficult use "loyal" units against "rebel" units. Moreover, the superiority of the armed forces in terms of training and armament disincentivized the use of police forces against them. In Portugal, paradoxically, the approach to control developed by the provisional governments was to a great extent similar to that of the Estado Novo. Salazarist coercive tools, such as PIDE/DGS and paramilitary Portuguese Legion, were abolished. However, the logic of coercive control was not abandoned. The special military unit COPCON, in charge of fighting insurgency, was the most

\footnotetext{
${ }^{54}$ Felipe Agüero Ibid, 214.

${ }^{55}$ Hood's (Ibid) organization resource is in this article divided into coercive power and organizational capacity.
} 
representative coercive instrument and participated in the neutralization of the right-wing mobilizations in September 1974 and the March 1975 coup. Later the Military Intervention Group (AMI), a strategic emergency unit under direct orders of the President, was established to counter the threat of COPCON to the new MFA-Moderate government. ${ }^{56}$ Other military units, the security forces, tribunals, prisons and even civilians acted as deterrents against military disobedience too. ${ }^{57}$ These instruments were nonetheless abandoned after the coup in November 1975.

\section{Organizational Capacity}

Organizational design became a central tool of control in both countries. In Spain, there was a gradual reorganization aiming to improve coordination among the branches and efficiency. The UCD government created new coordination bodies such as the Board of Joint Chiefs of Staff (JUJEM) and the Defence Ministry (1977). A new legal framework regulated the armed forces and concentrated decision-making power in the newly created Defence Ministry. ${ }^{58}$ The organization of the Defence Ministry was further reformed by the PSOE government. Power was concentrated in civilian hands and the three branches lost much of their autonomy. In Portugal, two different trajectories can be observed. During 1974 and 1975, new military institutions were introduced by the MFA to ensure military control on the political sphere and the politicization of the armed forces. The result was decentralization, fragmentation of power and problems of insubordination. From 1976, this trend was reversed; the Portuguese constitutional governments shaped the defence and military structures to centralize

\footnotetext{
${ }^{56}$ Arquivo Histórico Militar (AHM), Lisbon, division 1, section 40, box 1, number 29, COPCON Confidential Internal Report of the Army Ministry about the mission of AMI (12 November 1975)

${ }^{57}$ ACR, Correspondência classificada do secretariado coordenador, volumes 6, 8, 14, 17, 18, numbers 92, 94, 100, 103, 104.

${ }^{58}$ Manuel Ballbé, Ibid, p. 460.
} 
decision-making power and coordination. ${ }^{59}$ The defence structures were converging in both countries following NATO templates.

In Portugal, during the revolutionary period military education and training were neglected and the provision of services, goods and jobs continued as means to compensate poor salaries. From 1976, the reorganization efforts served to de-politicize the armed forces and de-militarize politics. Education and military training were reinforced through the action of the National Defence Institute (IDN), military academies as well as through joint exercises with NATO and allied countries. ${ }^{60}$ In 1976, the CR banned the provision of civilian jobs for the military in active service. ${ }^{61}$ In Spain, military education was used to bridge the gap with civil society by promoting democratic values, cooperation among branches and professionalism. The Centre of National Defence High Studies (CESEDEN) and the Institute of Strategic Studies were basic tools in this endeavour. Military training improved too. NATO membership introduced a series of joint exercises and courses with other armed forces providing a benchmark in terms of professionalism. The provision of services by the state organization was reinforced but the positions reserved for the military in the administration or public companies were eliminated. ${ }^{62}$

\section{Information Control and Politicization}

A feature of the Portuguese provisional governments was the reliance on information control and politicization as mechanisms of subordination. New information services, such as the Fifth Division, CODICE and SDCI, collaborated on an intensive propaganda campaign and the collection of evidence in the barracks concerning political affiliation and adherence to the MFA principles. Censorship was also used to suppress reactionary views and information about acts

\footnotetext{
59 Juan C. González Hernández, Ibid, 26.

${ }^{60}$ José J. Olivas, Iberian Military Politics: Controlling the Armed Forces during Dictatorship and Democratisation. London: Palgrave MacMillan, 2014, pp. 106-107.

${ }^{61}$ ACR, Actas - Originais, volume 3, 29 October 1976.

${ }^{62}$ FOG, interview General José Gabeiras Montero, 11 December 1987, cassette J31bis.
} 
of indiscipline and the decolonization process. ${ }^{63}$ However, after the failed November 1975 coup the idea of controlling the armed forces politically was abandoned and the propaganda and censorship apparatuses dismantled. ${ }^{64}$ Until the establishment of the new centralized secret services SIRP in 1984, the government had no intelligence services capable of controlling the military. In Spain, on the other hand, censorship and propaganda were not part of the transitional governments' strategy. Nonetheless, the unified intelligence services CESID, established in 1978 , became an important tool of control, especially after the $23 \mathrm{~F}$ coup attempt in 1981.

\section{Autonomy and Tolerance}

In both countries, governments were initially very permissive towards the military. The extraordinary degree of autonomy and the extensive functions granted to the military in this period were used as collective incentives for endorsing the governments' reforms. Soft disciplinary punishments, amnesty laws, promotions and political appointments were tools of control. In Portugal initially, some purges and sanctions were imposed on the military officers identified with the Estado Novo and anti-government activities. ${ }^{65}$ Nonetheless up to thirteen amnesty laws were enacted from 1974 to 1982 to reintegrate most officers to service. ${ }^{66}$ In Spain, the government promoted "liberal" militaries to key positions but applied very soft sanctions to reactionary plotters and acts of indiscipline. From 1982, this trend changed and in both countries regulations were then implemented to reduce their autonomy and increase professionalism. ${ }^{67}$ In Portugal, in 1982, the CR was abolished and the Constitutional Reform and the Law of National Defence and Armed Forces formalized for the first time the principle

\footnotetext{
${ }^{63}$ ACR, Actas Conselho da Revolução - Originais, volume 1.

${ }^{64}$ ACR, Actas - Originais, volume 2, 27 November 1975.

65 Ántonio C. Pinto, 'Authoritarian legacies, transitional justice and the state crisis in Portugal's democratization.' Democratization 13, no.2 (2007): 173-204, p. 177.

${ }^{66}$ The first import amnesty law was the Decree-Law 173/74 and the Law 17/82 was the last one

${ }^{67}$ José J. Olivas Ibid, pp. 105-107, 190-197.
} 
of civilian supremacy. In Spain, PSOE government introduced a no-tolerance policy, a new Military Penal Code and limited military autonomy and the jurisdiction of Military Courts. ${ }^{68}$

\section{Financial incentives}

The utilization of financial incentives to achieve military subordination was limited. Both countries attempted unsuccessfully to reduce the number of military personnel considerably to enable higher salaries for their officers. Although several general salary raises were approved military remunerations did not significantly increase in real terms due to the effects of inflation. Governments' financial resources were seriously compromised not only by the economic crisis but also due to the funds committed to the downsizing of the armed forces and, in Portugal, to the returning military from the colonies. The most significant change in military budgets observed was a gradual increase in the salience of equipment expenditure with the introduction of modernization and rearmament programme first in Spain, from the early 1970s, and then in Portugal, from 1985. Notwithstanding, military expenditure in both countries remained much lower than that of most other NATO allies and not a particular incentive for military satisfaction. $^{69}$

Table 2 Defence Expenditure as a Percentage of GNP

\begin{tabular}{llllllllllll} 
& 1974 & 1975 & 1976 & 1977 & 1978 & 1979 & 1980 & 1981 & 1982 & 1983 & 1984 \\
\hline Portugal & 4.71 & 5.74 & 5.29 & 2.91 & 3.25 & 3.7 & 3.2 & 3.68 & 2.7 & 2.65 & 3.23 \\
\hline Spain & 1.85 & 2.12 & 1.87 & 2.11 & 1.91 & 2.64 & 2.91 & 2.44 & 2.1 & 1.86 & 2.35 \\
\hline Italy & 2.93 & 2.58 & 1.95 & 2.87 & 2.61 & 2.36 & 2.07 & 2.09 & 2.25 & 2.21 & 2.22 \\
\hline UK & 4.62 & 5.3 & 4.58 & 4.81 & 4.94 & 5.81 & 6.21 & 5.02 & 5.5 & 5.3 & 5.3 \\
\hline France & 4.65 & 4 & 2.97 & 3.31 & 4.67 & 4.64 & 3.57 & 3.73 & 3.51 & 3.23 & 8.25 \\
\hline
\end{tabular}

Based on CESEDEN ${ }^{70}$

Figure 1 Defence Budget as a Percentage of Total Public Expenditure

${ }^{68}$ Jesús Valenciano Almoyna, 'La reforma de la justicia militar en España durante la transición.' Revista Española de Investigaciones Sociológicas, 36, (1986): 141-152, pp. 147-152.

${ }^{69}$ Nuno Valério, Portuguese Historical Statistics, Lisbon: INE, 2001, pp. 814-831; Francisco Pérez Muinelo, El Gasto de Defensa en España: 1946-2009. Madrid: Ministerio de Defensa, 2009, pp. 91, 93, 114, 116.

${ }^{70}$ CESEDEN, Estudio Comparativo de la Evolución de los presupuestos de defensa de los países del 


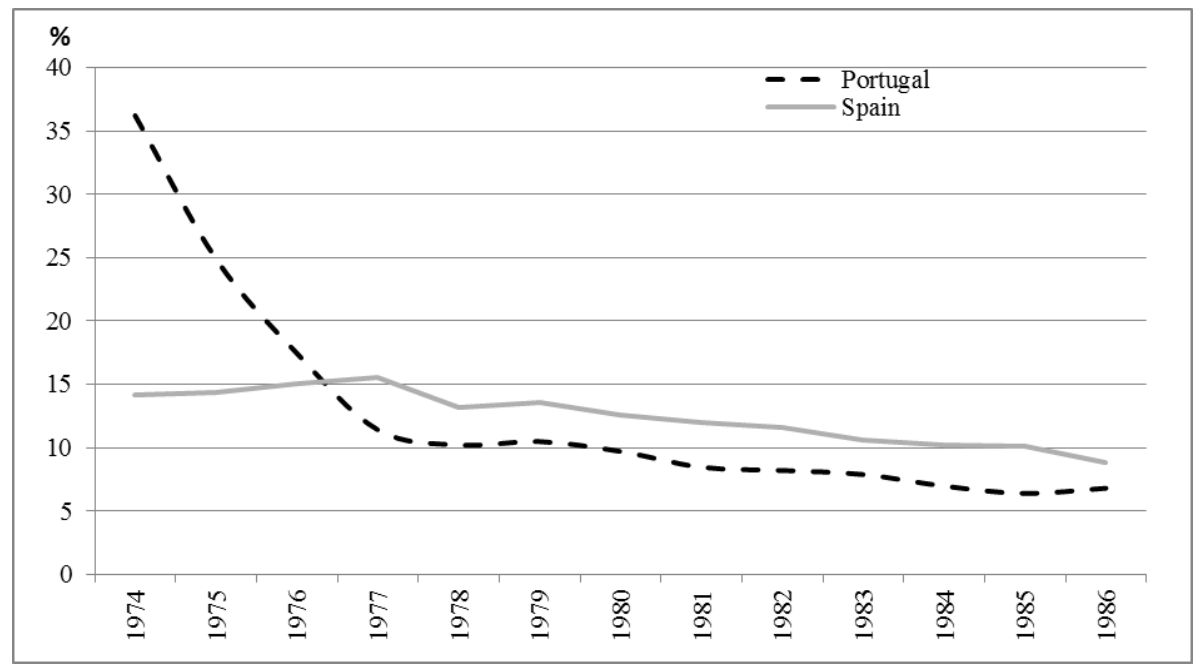

Based on Mata and Valerio and Pérez Muinelo ${ }^{71}$

\section{Historical Legacies: The Impact of Wars}

The Spanish Civil War, Second World War and the colonial conflicts affected the attitude of the military as well as the governments' control toolkit. These wars partially acted as external shocks and help explain the different civil-military dynamics and problems in Portugal and Spain during transition.

\section{Spanish Civil War}

The first important event whose legacy affected military politics was the Spanish Civil War. Franco's legitimacy as ruler was built on his military victory against the Republic. ${ }^{72}$ The war allowed Franco to purge the armed forces from anyone suspected critical of his regime. ${ }^{73}$ Franco managed to transform the Spanish Armed Forces into what can be considered the "Francoist Armies": a new institution virtually disconnected from its past as Armies of the

área mediterranea (1971-1985) Madrid, 1988, p.120.

${ }^{71}$ Eugénia Mata and Nuno Valerio. História Económica De Portugal: Uma Perspectiva Global. Lisbon: Fundamentos, 1994, pp. 70-71, 253-254; Francisco Pérez Muinelo, Ibid, p. 84.

${ }^{72}$ Mariano Aguilar Olivencia, El Ejército Español durante el Franquismo. Madrid: Akal, 1999, pp. 38-39.

${ }^{73}$ Paul Preston, El Holocausto Español. Odio Y Exterminio En La Guerra Civil Y Después, Barcelona: Debate, 2011, p. 17. 
Second Republic. ${ }^{74}$ Due to the atrocities committed during and immediately after the war, Franco's regime was isolated by the international community. This isolation limited economic exchanges but also contacts with other armies and obstructed the influx of new ideas. The already dire economic situation was aggravated. The wide gap in terms of material conditions between Spain and most West European armies, as well as the lack of resources to bridge it, pushed the government to focus on ideological indoctrination to shield the military from a sad reality. Later, self-recruitment as well as the elitism, education and socialization of the military acted as a self-reinforcement mechanism perpetuating a frozen military ideology. ${ }^{75}$

In sum, the Civil War provoked a critical juncture which introduced a dynamic of "path dependence" 76 It deeply changed Spanish armed forces and introduced a series of self-perpetuating mechanisms that contributed to an ideologically cohesive military and a much higher degree of obedience to the dictator than in Portugal. During the transition the conservatism and allegiance to the Francoist authoritarian principles made it more difficult for the military to accept democratization.

\section{Second World War and NATO}

In Portugal, Salazar managed to use the threat of the Second World War to consolidate his political leadership and authority. The Western Allies rewarded the Estado Novo for the country's collaboration by inviting Portugal to join NATO in 1949. NATO membership brought about some important changes in military attitudes contributing to the divergent paths of civil-military relations in Portugal and Spain. The Spanish military continued to be isolated, concentrated on internal threats and recalling their past glory. On the other hand, many

\footnotetext{
${ }^{74}$ FOG, interview Lieutenant-General Sáenz de Tejada, 7 November 1987, cassette J25.

75 José A. Olmeda, La fuerzas armadas en el estado franquista: participación política, influencia presupuestaria y profesionalización, 1939-1975. Madrid: Ediciones El Arquero, 1988, pp. 290-292.

${ }^{76}$ Paul Pierson, Politics in Time: History, Institutions and Social Analysis. Princeton: Princeton University Press, 2011, pp. 17-53.
} 
Portuguese military officers went to study abroad and participated in NATO bodies and activities becoming aware of the deficiencies of the Portuguese Armed Forces and political system. This contact transformed a generation of young officers, the "NATO generation" ${ }^{77}$ These officers became influential and later developed and spread critical thinking within the ranks, which was an important cause for the fall of the Estado Novo and for the initiation of the democratization process. ${ }^{78}$

\section{Colonial Wars}

Portuguese Colonial Wars (1961-1975) forced the Estado Novo government to change its military and defence strategy and priorities. Salazar adopted rigid stance and refused to negotiate their independence. ${ }^{79}$ The Colonial Wars exacerbated military unrest. In 1961, the independence war broke out in Angola and Portuguese military surrendered Goa, Damao and Diu to the Indian Armies. The military considered the government plans of maintaining all the overseas territories by sheer force as unrealistic. ${ }^{80}$ With the extension of the conflict to Guinea (1963) and Mozambique (1964), the wars drained the government's resources and legitimacy. There were many complaints about the insufficient material conditions, lack of expertise and about the negative treatment that the regime's propaganda machinery was giving the armed forces. ${ }^{81}$ The dispersion of the armies contributed to the emergence of factions with different political views and caudillist military leaders not always aligned with the government. Many members of the military adopted leftist and revolutionary ideologies and in some cases even sympathized with the African insurgents. Massive recruitment for the wars also contributed to

\footnotetext{
${ }^{77}$ Antonio J. Telo, Portugal e a NATO : o reencontro da tradicão atlântica. Lisbon: Edições Cosmos, 1996, pp. 84-85.

${ }^{78}$ AHM, division 1, section 40, box 1, number 47, 'Chronicle of events of April 1974' by Captain Salgueiro Maia.

${ }^{79}$ Richard Mahoney, JFK: Ordeal in Africa, Oxford: Oxford University Press, 1983, pp. 187-222

${ }^{80}$ AHM, division 1, section 39, box 1, number 1, documents 23, 28 and 29, 16 April, June 1961 and 25 July 1961.

${ }^{81}$ AHM, division 1, section 39, box 1, number 1, documents 1, 3, Captain Ferreira Valença's report 'A Abrilada 1961', 1977.
} 
socially and ideologically heterogeneous composition of the armed forces. The long Portuguese Colonial Wars had a cumulative effect on military dissatisfaction. The military dissatisfaction generated by the Colonial Wars was amplified by the new critical thinking introduced by the "NATO generation" becoming a fundamental cause for the fall of the regime. ${ }^{82}$

Conversely in Spain the colonial problem had a limited impact on civil-military relations. Spain recognized the independence of Morocco in 1956, that of Equatorial Guinea in 1968 and transferred the sovereignty of the possessions in Sahara to Morocco and Mauritania in 1975. Decolonization was therefore peaceful except for the Sidi-Ifni War in Western Sahara (19571958) which highlighted the deficiencies of the armed forces. ${ }^{83}$ However, the scale of this conflict was small compared to the Portuguese Colonial Wars and its impact on the military political attitude and subordination very limited.

\section{Contextual Factors}

Although history matters, these wars and the inertias they introduced do not account for all the variations observed. The ideational context, international environment and political institutional setting in which the political transformation took place also impacted civil-military relations and the control instruments during the Iberian transitions.

\section{Ideational Context}

Concerning the ideational context three factors are easily distinguishable. First, developmentalist ideas, introduced in the 1960s, contributed to the constant decline of defence budgets relative to total public expenditure and to a drop of the percentage of military officers

\footnotetext{
${ }^{82}$ José M. Ferreira, Cinco Regimes na Política Internacional, Lisbon: Presenta, 2006, p. 60.

${ }^{83}$ Gastón Segura Valero, Ifni. La guerra que silenció Franco. Madrid: Martínez Roca, 2006, pp. 218-22-, 246-251, 311-312.
} 
working in the public administration in both countries. Expenditure on public infrastructure, education and agriculture, was prioritized in both countries. ${ }^{84}$

Second, the personal experiences of the Portuguese officers during the Colonial Wars influenced civil-military relations. The counter-insurgency techniques that were intensively used in Africa marked the strategic thinking of the military who led the provisional governments. The intensive utilization of political propaganda, censorship, and intelligence services during the transition as well their politicization are the clearest examples of this influence. The military was also exposed to socialist and communist ideas during the conflict, to the extent that many embraced them. The MFA parallel structures of political control imitated the organization of some contemporary leftist parties and organizations. Finally, the use of loyal civilians to counter military insurgency, as in November 1975, was inspired by the utilization of paramilitary groups of settlers in the African conflict. ${ }^{85}$

Third, in Spain the majority of the military was very conservative and most members of the UCD government had been involved in the previous regime apparatus and were averse to drastic changes. This helps explain the insufficient military reforms and high degree of military autonomy during Suárez's governments. The military continued to think that the Defence Minister and the government remained merely administrators of military budgets. ${ }^{86}$ Moreover, the traumatic memories of the Civil War also made decision-makers behave very cautiously and avoid measures that could disturb hardliners and provoke their intervention in politics.

In sum, shared ideologies, personal experiences and views of the military and political leaders influenced civil-military relations and the strategies for military subordination.

${ }^{84}$ Diogo F. Amaral, 'Forças Armadas em Regime Democrático,' Nacão e Defesa, 94 (2000): pp. 175-185, p. 184; Francisco Comín and Daniel Díaz. 'Sector publico administrativo y estado del bienestar', in Estadisticas Historicas de España, Siglos XIX-XX edited by Abel Carreras and Xavier Tafunell. Bilbao: Fundación BBVA, 2005, pp. 929-934.

${ }^{85}$ Tiago Fernandes, Nem ditadura, nem revolução: a Ala Liberal eo Marcelismo, 1968-1974. 


\section{International Environment}

Some international actors influenced civil-military relations through normative pressures and by stimulating and constraining the availability of government resources.

Portuguese political and military leaders sought international recognition after the 25 April coup but the ideological fragmentation of the MFA obstructed a coherent strategy concerning foreign affairs. For instance, Vasco Gonçalves sought international support in the Eastern Bloc, Otelo in Cuba and Rosa Coutinho in Velasco's Peru. Although USSR kept good relations with the MFA, its influence and participation was limited in Portuguese transition. Both German states were more actively involved in the process, East Germany supporting the communist approach and West Germany the Western democratic model. The US initially maintained a distant approach that can be captured by Kissinger's reference to the Portuguese revolution as a "vaccine" against future communist revolutions. NATO also put pressure on the MFA governments and temporarily discontinued collaboration with Portugal. After the failed coup of November 1975, thanks to the mediation of ambassador Carlucci, the US decided to support the MFA-Moderates to consolidate their position. ${ }^{87}$ The influence of NATO allies became stronger and was used by the political leadership to legitimize the reforms and consolidate military subordination.

The convoluted experience of the first part of Portuguese transition decisively influenced Spanish government's strategy. The Portuguese problems during 1974 and 1975 reaffirmed Suárez's conviction of a piecemeal transition without military involvement. Similarly, Portuguese revolutionary drift exacerbated military fears of communist involvement in the Spanish transition. Further integration into Europe and the Western bloc was one of the main

Lisbon: Dom Quixote, 2006, pp. 162-166.

${ }^{86}$ Fernado Puell de la Villa, Ibid, p. 236.

${ }^{87}$ Bernardino Gomes and Tiago Moreira de Sá, Carlucci Vs Kissinger - Os Eua E a Revolução Portuguesa. Lisbon: Dom Quixote, 2008, pp. 212-214. 
reasons for launching the political reforms in Spain. In 1976, Spain signed a new treaty of cooperation with the US and applied for NATO membership. After the 23F coup in 1981, the idea of joining NATO became a priority. Politicians considered this as a means of diverting the attention of the military away from domestic politics. Membership was made official in 1982. The normative pressures from NATO and the more frequent exchanges with other Western armed forces can be interpreted as the main explanation for the convergence of the trajectories of civil-military relations and control instruments in the peninsula after 1982. NATO doctrine justified changes in organization and strategic planning of the armed forces and a growing presence of civilian personnel in the Defence Ministry. ${ }^{88}$

\section{Political Institutional Context}

Finally, the political institutional setting influenced civil-military relations and the instruments of control too. In Portugal, the military subverted the traditional relations of power. The government was subordinated to military executive bodies. Military supremacy in politics did not contribute to military subordination in the barracks. In Spain, on the other hand, civilian political actors led the dissolution of the regime. The military lost the agenda-setting power and did not participate in any of the core political decisions. This exclusion from political decisions created frustration.

Executive and legislative power was much more fragmented after the end of the dictatorships. The supremacy of governments was reduced and new actors acquired the capacity to shape or obstruct policy choices. In Spain, during Suárez's minority governments, the military gained autonomy. The newly created Defence Ministry was in a weak position vis-à-vis the three military branches. In 1979, only 5 per cent of the budget was controlled by the central

\footnotetext{
${ }^{88}$ Richard Gillespie, The Spanish Socialist Party: A History of Factionalism. Oxford: Oxford University Press, 1989, p. 425.
} 
coordination body of the ministry. ${ }^{89}$ The formal legal subordination of the armed forces to civilian rule remained ambiguous. The veto power of the military was evident. Some of the reforms were slowed down by the military ministers and other top rank officers, the practice often did not follow the formal principles and regulations. ${ }^{90}$ Conversely, the González's government, having a comfortable majority in the parliament and wide public support, managed to curb the autonomy and veto power of the military and to introduce fundamental reforms.

In Portugal, the fragmentation of power marked civil-military relations even more profoundly. During the period of provisional governments, the continuous reshuffles of governments, the multiplicity of bodies sharing governmental functions and the hierarchical subordination to the President and not to the Defence Ministry undermined the capacity of the government to reform civil-military relations. Political parties were very weak and the public administration grew. Many public servants were replaced by political appointees. ${ }^{91}$ In this situation characterized by reversals in policy choices, internal grievances and bureaucratic barriers governments held on to a control strategy that was basically a continuation of that of the Estado Novo; especially in terms of coercive power, propaganda, censorship and scrutiny of the military. Inertia and red tape prevailed until 1976. From 1976 to 1982, veto players such as the CR, the President, political parties and the military were responsible for slowing down some of the reforms. ${ }^{92}$ The institutional consolidation of Western-type of democratic regimes contributed to stability and convergence in these countries after 1982.

${ }^{89}$ Fernando Rodrigo, El camino hacia la democracia: militares y política en la transición española, Madrid: Universidad Complutense, 1989, p. 307.

${ }^{90}$ Manuel Ballbé, Ibid, p. 469-488.

${ }^{91}$ Lawrence S.Graham 'Bureaucratic Politics and the Problems of Reform of the Apparatus' in In Search of Modern Portugal:e Revolution and Its Consequences edited by Lawrence S.Graham and Douglas L. Wheeler, Madison, Wisconsin: The University of Wisconsin Press, pp. 228, 232-243.

${ }_{92}$ Lawrence S. Graham, The Portuguese Military and the State: Rethinking Transitions in Europe and Latin America. Boulder: Westview Press, 1993, p. 49. 


\section{Two Successful Transitions: Different Paths, Similar Challenges}

Portuguese and Spanish civil-military relations illustrate the challenges that the armed forces may pose in countries experiencing political transitions. The different trajectories in terms of democratization and civil-military relations can be used to establish comparisons and draw lessons relevant for countries currently undergoing deep political transformations and military threats.

The Portuguese transition originated from a military coup and a revolutionary movement. Significant purges took place in government institutions and the armed forces. Conversely, the Spanish transition was launched by reformists within the regime and no purge of the state apparatus was conducted. In both countries, the military challenged the principle of civilian supremacy and threatened the political reforms.

The composition of the Portuguese Armed Forces was much more heterogeneous, both ideologically and socially, than that of the Spanish Armed Forces. While in Portugal the left-wing military provided the initial impulse for democratization, in Spain most military were very conservative and opposed to transition to democracy. The roles of the military were also very different. In Portugal, the MFA military occupied the main posts in the government and advisory bodies; in Spain the military lost the agenda-setting power and remained mainly spectators of the political decisions. Whereas in Spain the military were reluctant to be subordinated to the transition governments, in Portugal the military controlled the transition governments. Both letting the military take the lead in the reforms, as in Portugal, and ostracizing them from the most important decisions, as in Spain, proved problematic strategies. 
This paper has also contrasted the main policy instruments employed by the transitional governments to consolidate civilian supremacy. The control toolkit differed significantly until 1982. The Portuguese governments used coercion to deter insurrections as well as intensive propaganda, censorship and political surveillance to indoctrinate the military. In Spain, on the other hand, intrusive means of control were avoided and the focus was on gradually reforming the organization of the armed forces to concentrate power within government. Neither of these initial strategies generated an equilibrium or self-reinforcing dynamics that would have contributed to military subordination. On the contrary, they created a window of opportunity for military plotters to try to overthrow the newly established governments.

However, the failure of the coups d'état attempted in both countries strengthened the authority of the governments and legitimized new military policies aiming at tightening civilian control. The firm governmental responses to these military challenges were extremely important to create a turning point in civil-military dynamics paving the way for consolidation of democracy. In Portugal the failed revolutionary coup of 25 November 1975 was a first step for the withdrawal of the military from politics, later accomplished with the constitutional and defence reforms launched in 1982. In Spain, after the reactionary 23F coup attempt in 1981 and NATO membership in 1982, the new socialist government gave a decisive impulse to the process of military subordination and consolidation of democracy. The countries experienced a process of convergence in civil-military relations from 1982 onwards, which was reflected in the type of new control policies implemented. Centralizing power on civilian hands and instilling professionalism in the ranks became the new priorities.

Finally, this paper has shown that the evolution of civil-military in the Iberian countries was the result of the interplay of "historical causes", legacies of armed conflicts, and "constant causes", the continuing effect of contextual factors. This has important implications for democratization studies. While new democratic ideas, political institutional reforms and the support from 
international actors may be necessary conditions for a successful transition, they do not guarantee military subordination. As the Iberian cases show, the legacies of past historical events, such as the Spanish Civil War, Second World War and Portuguese colonial conflicts, often have longstanding consequences on governments' toolkits and can shape the outcome of democratization processes.

\section{Acknowledgements}

I would like to thank Fundación Ramon Areces, Fundación Caja Madrid and the University of London for their financial support that made possible the research for this article. 